\title{
O PODER DE PERSUASÃO DA MÍDIA FRENTE AOS PRINCÍPIOS E GARANTIAS DO AGENTE DELITUOSO
}

\author{
Douglas da Silva Araújo 33 \\ Patrícia Borba Vilar Guimarães ${ }^{34}$ \\ Jônica Marques Coura Aragão ${ }^{35}$
}

Recebido em: $31 / 10 / 2017$

Aprovado em: 08/06/2018

\begin{abstract}
RESUMO
A violência criminal e a falta de segurança pública são problemas que têm se alastrado de forma muito intensa na última década. Nesse contexto, observa-se uma grande força da mídia em suas mais variadas formas de propagação da notícia. A pesquisa tem como objetivos analisar a interferência midiática na dinâmica processual penal brasileira, especialmente o princípio do estado de inocência. Empregar-se-á o método hipotético-dedutivo e como técnica de pesquisa será utilizada a bibliográfica, bem como a documental. Cuida-se de um estudo comprometido com a análise hodierna das ingerências do comportamento da mídia nacional à luz do marco teórico garantista.
\end{abstract}

Palavras-Chave: Ação midiática. Presunção do estado de inocência. Garantismo penal.

\section{INTRODUÇÃO}

O problema da violência e da falta de segurança pública tem se alastrado de forma muito intensa na última década. A sociedade vive aterrorizada e tudo é motivo para que se instale o pânico. Paralelo a essa questão, vem se observando uma grande força da mídia em suas mais variadas formas de propagação da notícia, curiosamente, percebe-se que dentre a

\footnotetext{
${ }^{33}$ Mestrando do Programa de Pós-graduação em Direito da Universidade Federal do Rio Grande do Norte (UFRN). Especialista em Ciências Criminais e Segurança Pública pela Faculdade Integrada de Patos/PB (FIP).

${ }^{34}$ Doutora em Recursos Naturais pela Universidade Federal de Campina Grande (UFCG). Mestre em Direito pela Universidade Federal do Rio Grande do Norte (UFRN). Mestre pelo Programa Interdisciplinar em Ciências da Sociedade pela Universidade Estadual da Paraíba (UEPB). É Advogada e Professora da UFRN.

${ }^{35}$ Doutora em Ciências Jurídicas e Sociais pela Universidad Del Museo Social Argentino, com reconhecimento formal pela Universidade Federal de Campina Grande (UFCG). Doutoranda no Programa de Recursos Naturais da UFCG. Mestre em Desenvolvimento e Meio Ambiente pela Universidade Federal da Paraíba (UFPB). Especialista em Direito Processual Civil pela UFCG. Professora Adjunto II da UFCG.
} 
variada gama de notícias veiculadas, as que mais despertam o interesse e prendem a atenção de todos os segmentos sociais, são exatamente aquelas que relatam casos criminais, especialmente quando expressadas em formato sensacionalista e especulativo.

Nesse contexto, o presente estudo terá como objetivo geral analisar a interferência midiática na dinâmica processual penal brasileira, em especial quanto aos princípios processuais penais de viés garantista, especialmente o princípio do estado de inocência.

Os objetivos específicos destacar-se-ão como sendo: traçar o perfil da mídia jornalística na área criminal no que diz respeito a observância das regras e princípios processuais penais; identificar os ideais garantistas mais frontalmente atingidos com o exagero sensacionalista da mídia; visualizar opções jurídicas de reparação dos danos causados ao acusado.

Para tanto, empregar-se-á o método hipotético-dedutivo, partindo da hipótese que a exposição midiática malfere direitos e garantias individuais do acusado no processo penal. Como técnica de pesquisa será utilizada a bibliográfica, bem como a documental indireta, com a finalidade de tornar a pesquisa mais precisa as suas informações.

Assim, ao longo do trabalho será discutida a temática sob uma abordagem constitucional, observando-se indeclinável referência ao garantismo penal, seu conceito e demais especificações acerca dessa premissa, e como a mídia pode desvirtuar essa garantia conferida ao agente delituoso. Ato contínuo será ponderado sobre o princípio da presunção da inocência, numa avaliação referente ao poder da imprensa na violação dessa garantia individual. E por fim, serão demonstrados alguns institutos jurídicos pensados para reparar os danos causados ao princípio do estado de inocência.

\section{O PODER DE PERSUASÃO DA MÍdIA FRENTE AOS PRINCÍPIOS E GARANTIAS DO AGENTE DELITUOSO}

A mídia, atualmente, é grande responsável pela formação de opinião da população de forma geral. Não é por acaso que a mídia recebeu o epíteto de quarto poder, já que, o que é vinculado por ela influencia fortemente a opinião pública, chegando a ditar regras de comportamento, interferir na vontade das pessoas, como também, alterar o próprio convívio social.

No ramo do direito penal, a mídia afigura-se como uma espécie de julgadora ao atribuir juízo de valor a determinados casos difundidos nos diversos meios de comunicação, 
interferindo frontalmente na culpabilidade penal que é exatamente o juízo de reprovabilidade da conduta perpetrada pelo agente delituoso.

Seguindo a postura jurídica pautada em um referencial teórico garantista torna-se inevitável o embate sócio-jurídico com a mídia. Malgrado se saiba que o conhecido jargão forense sentencie o que não está nos autos, não está no mundo; mas tudo o que está no mundo, está na mídia; inclusive o que está (ou não) nos autos acerca dos casos criminais, especialmente aqueles mais polêmicos. Por essa razão, a posição da mídia é sempre motivo de preocupação ao acusado e ao seu advogado.

2.1 Garantismo Penal: A proteção do réu nos processos penais

O garantismo penal é composto por dez axiomas, sequenciais e lógicos, que se dividem em garantias penais e processuais penais, dispondo a referida teoria que o Estado, embora dotado do poder de punir (jus puniendi), terá que fazê-lo em observância a todos os direitos e garantias individuais certificados ao cidadão; ou seja, ao sujeito investigado, processado ou condenado deverão ser asseguradas as mais amplas e diversas garantias que permitam não lhe sejam indevidamente subtraídos direitos.

Luigi Ferrajoli, precursor do garantismo penal, desenvolveu tal estudo visando fortalecer as garantias do cidadão em face do poder punitivo do Estado, priorizando a liberdade como direito fundamental do indivíduo frente às arbitrariedades cometidas pelo Estado.

Sob um enfoque político, substancial e social, considerando os aspectos do garantismo, pode-se dizer que o Estado de Direito representada à exteriorização da democracia, no sentido que reflete, além da vontade da maioria, os interesses e necessidades vitais de todos. Neste sentido, o garantismo, como técnica de limitação e disciplina dos poderes públicos, voltado a determinar o que estes não devem e o que devem incidir, pode ser concebido como a conotação (não formal, mas) estrutural e substancial da democracia: as garantias, sejam liberais ou sociais, exprimem de fato os direitos fundamentais dos cidadãos contra os poderes do Estado, os interesses dos fracos respectivamente aos dos fortes, a tutela das minorias marginalizadas ou dissociadas em relação às maiorias integradas, as razões de baixo relativamente às razões do alto. (FERRAJOLI, 2010).

Por sorte, o garantismo penal teve influência dos ideais iluministas. Nessa época, os pensadores defendiam a liberdade, a justiça, a igualdade social, a divisão dos poderes do 
Estado, fatores essenciais à construção de uma sociedade justa e igualitária. Sobre este ponto, Choukr (1999) argumenta o seguinte:

\begin{abstract}
Antes de tudo, é necessário recordar que o garantismo nasce no âmbito dos direitos individuais, na tradição iluminista, como forma de limite ao poder soberano estatal (liberdade pessoal, de consciência, etc.), sendo necessário precisar, ainda, que teve muita influência nesse processo a estipulação dos direitos positivos sociais, agregados aos direitos negativos de liberdade.
\end{abstract}

Como visto, a busca pela concretização dos direitos individuais estava em evidência nessa época, principalmente no que diz respeito aos ideais de igualdade e liberdade, sendo o movimento iluminista contrário às desigualdades de direitos e deveres entre os indivíduos.

Válido destacar agora o conceito de garantismo penal apresentado por Ferrajoli (2010, p. 108):

\begin{abstract}
Garantismo, com efeito, significa precisamente a tutela daqueles valores ou direitos fundamentais, cuja satisfação, mesmo contra os interesses da maioria, constitui o objetivo justificante do direito Penal, vale dizer, a imunidade dos cidadãos contra a arbitrariedade das proibições e das punições, a defesa dos fracos mediante regras do jogo igual para todos, a dignidade da pessoa do imputado, e, consequentemente, a garantia da sua liberdade, inclusive por meio do respeito à sua verdade. É precisamente a garantia desses direitos fundamentais que torna aceitável por todos, inclusive pela maioria formada pelos réus e pelos imputados, o Direito Penal e o próprio princípio majoritário.
\end{abstract}

Como se pode fazer inferência do próprio nome, garantismo penal é a tutela dos direitos do acusado, isto é, procura assegurar os direitos e liberdades do acusado, fortalecendo o direito penal mínimo.

O garantismo busca, de forma sinóptica e objetiva, garantir uma maior efetividade aos direitos e garantias fundamentais do indivíduo, no que tange ao ramo do direito penal, tal garantismo busca dar maior ênfase ao direito de liberdade, mitigado muitas vezes pelas arbitrariedades cometidas pelo Estado.

Tal garantismo muitas vezes é ameaçado pelo sentimento sensacionalista transmitido pela mídia, distorcendo o conhecimento popular, e consequentemente invadindo o campo de garantias do agente delituoso.

A massa populacional é eivada do sentimento de fazer justiça, muitas vezes plantado pelas informações e notícias sensacionalistas repassadas pela mídia diante, na maioria das vezes, da difusão de casos com repercussão nacional que enchem os cidadãos de ódio, de sentimento de vingança, de busca pela solução do caso.

Sobre o assunto, Schütz (2011, p. 02) faz as seguintes considerações: 
Existe uma necessidade no anseio social de que os direitos constitucionais sejam garantidos de forma eficaz quando da ocasião de exploração de fatos criminosos pela mídia. $\mathrm{O}$ atendimento a essa necessidade revela o respeito aos direitos fundamentais e ao processo de formação de um Estado de Direito ideal e pleno, visando reverter o quadro alarmante de acusação sem provas, julgamento e condenação feitos pela grande maioria da população brasileira.

Acrescenta ainda:

O problema do clamor público gerado pelo sensacionalismo da mídia não se trata de mera tecnicidade jurídica, pois os direitos e garantias constitucionais que fundamentam o Direito é que protegem o homem do autoritarismo e do arbítrio estatal influenciados pela televisão (SCHÜTZ, 2011, p. 02).

Como visto, as pessoas, influenciadas pelo sensacionalismo midiático, clama por um ideal de justiça, que na verdade constitui a implementação dos direitos e garantias constitucionalmente assegurados aos indivíduos.

Os direitos e garantias individuais assegurados pela Constituição Federal foram frutos de batalhas longas, de discussões e mitigações que ao longo dos anos foram se efetivando até se tornar o que é hoje.

A Constituição Federal preceitua em seu artigo $5^{\circ}$, inciso LVII que "ninguém será considerado culpado antes do trânsito em julgado de sentença condenatória (BRASIL, 2014, p. 23)".

Veja-se que tal premissa máxima garante o status de inocência do agente até que se tenha uma sentença condenatória. Quando o povo, diante da publicidade de determinado caso, fortemente inflamado pela mídia, clama pelo ideal de justiça, pedindo a condenação do acusado, fere frontalmente as garantias do contraditório e do devido processo legal, uma vez que, não se pode falar em condenação sumária de pessoas envolvidas em fatos delituosos, desvirtuando assim o garantismo assegurado ao agente. Argumenta Schütz (2011, p. 03):

Conflitos existem, entretanto, como fontes que geram violência, e, antes de condenála de uma maneira rápida demais com base nas informações fornecidas pela mídia, é melhor ver de que maneira se posicionar perante ela. Assim, surge o direito penal garantista, quando o conflito entre o ofensor e o ofendido passa a ser solucionado pelo poder estatal, que, para tanto, utiliza-se das penas, das proibições e dos processos como forma de controle do desvio social.

O Estado, enquanto detentor do poder punitivo deve usar meios legais para que se efetive a sanção penal imposta àquele que agiu de forma contrária aos parâmetros socais. Contudo, o garantismo vem ao encontro desse poder punitivo, assegurando a sua efetivação dentro dos limites legais e impedindo que arbitrariedades aconteçam.

Sobre os princípios acoplados ao garantismo, Matos (2012, p. 01) alude que: 


\begin{abstract}
Os princípios em que se fundam o garantismo penal são o princípio da legalidade em que se cogita a inviabilidade da condenação de uma pessoa e a aplicação de uma pena se não existir expressa previsão legal, devidamente compatível com a Constituição vigente; o da retributividade; o princípio da necessidade em que só deve ocorrer ao direito penal quando necessário; o princípio da lesividade em que o ato deva causar lesividade ou ofensividade ao bem jurídico protegido; o princípio da culpabilidade onde a responsabilidade criminal é do agente que praticou o ato, desde que comprovada a sua culpabilidade; o princípio da materialidade; o da jurisdicionalidade; princípio acusatório em que o réu tem direito de saber sua acusação e amplo direito de defesa das acusações que lhe são feitas; princípio do encargo da prova em que a acusação tem obrigação de provar a responsabilidade criminal do imputado.
\end{abstract}

Os princípios acima descritos asseguram ao agente delituoso garantias previstas constitucionalmente. Dentre eles, pode-se destacar o princípio da legalidade, o princípio da necessidade, o princípio da lesividade, o princípio da culpabilidade e as garantias a ampla defesa e ao contraditório.

O princípio da legalidade, previsto no art. $5^{\circ}$, inciso XXXIX, da Constituição da República aduz que "não há crime sem lei anterior que o defina, nem pena sem prévia cominação legal" (BRASIL, 2014, p. 22), é constituído por regras, dentre elas a da taxatividade, a qual denota que as condutas proibidas devem necessariamente está previstas em lei, ou seja, devem ser tipificadas.

Quanto ao princípio da necessidade, o mesmo remonta que o Direito Penal só deverá intervir quando for a última instância, a última solução para a normalização diante do caso apresentado, demonstrando assim a ideia de excepcionalidade. Em outras palavras, o Estado só deverá aplicar uma pena ao indivíduo quando for inteiramente necessário, quando não se possa proteger o bem jurídico de outra forma.

Por sua vez, o princípio da lesividade, com previsão no art. $5^{\circ}$, XXXIX, da Constituição Federal e art. 13, caput, do Código Penal, ensina que somente a conduta que interfere nos interesses de outra pessoa deverá ser criminalizada, ou seja, enquanto a conduta insurgir apenas na espera de interesses do próprio indivíduo não haverá criminalização da mesma.

Já o princípio da culpabilidade, como já exaustivamente abordado no primeiro capítulo deste estudo, consiste em um juízo de reprovabilidade que se faz sobre a conduta (fato) típica e ilícita do agente, visto que, não podemos reprovar ninguém pelo que é, ou pelo que pensa. (GRECO, 2005).

Quanto às garantias da ampla defesa e do contraditório, a mídia pode insurgir também sobre tais premissas. O indivíduo ao ser acusado de um fato delituoso tem o direito de ampla defesa assegurado pela própria Constituição, porém a sociedade moralmente influenciada pelo 
sensacionalismo midiático consegue atribuir um juízo de valor negativo ao agente, que caso consiga provar sua inocência já tem caído no esquecimento, ou já foi julgado moralmente pela população, continuando mesmo assim como a figura estereotipada de culpado, bandido, assassino etc.

Neste diapasão, Santos (2013, p. 03) salienta que:

\begin{abstract}
Não custa enfatizar sobre as influências da mídia na sociedade e no processo penal e suas consequências danosas ao acusado criminalmente. Registre-se que os meios informativos de massa formam a opinião pública, causam o medo, o terror, a insegurança e a falsa realidade do momento social vivido.

Além disso, provocam um clima de indignação, a comoção social, o clamor e a pressão popular sobre os atores do processo, podendo resultar danos irreparáveis ao suspeito, como a exclusão social, a prisão cautelar ilegal, ou seja, a pena pelo crime supostamente cometido por ele já começa a ser cumprida no momento da persecução penal, o prejulgamento no Tribunal do Júri, e, por fim, a condenação do suspeito sem o respeito ao princípio constitucional do devido processo legal e à ampla defesa.
\end{abstract}

Já em relação ao princípio do contraditório, o mesmo mostra-se amparado no art. $5^{\circ}$, LV da Constituição Federal de 1988. Tal princípio é comum tanto para acusação quanto para a defesa. Nucci (2008, p. 84) preleciona:

[...] quer dizer que a toda alegação fática ou apresentação de prova, feita no processo por uma das partes, tem o adversário o direito de se manifestar, havendo um perfeito equilíbrio na relação estabelecida entre a pretensão punitiva e o direito à liberdade $\mathrm{e}$ à manutenção do estado de inocência do acusado (art. $\left.5^{\circ}, \mathrm{LV}, \mathrm{CF}\right)$.

Todavia, diante de casos de grande repercussão na mídia, é muito comum que operadores e/ou estudiosos do direito lancem opiniões ou defendam o seu posicionamento sobre determinado caso. Diante disso, na atuação dos meios de comunicação o princípio do contraditório encontra-se mitigado, já que, quase sempre, não são ambas as partes que têm direito ao acesso a esses meios como forma de demonstrar sua parcela de interferência naquela situação. Na grande maioria das vezes, sempre são as vítimas que tem a disposição o uso desses referidos meios.

Sendo assim, a defesa do acusado já sai em desvantagem, uma vez que, a própria sociedade já se mostrou contra e já atribuiu um juízo de valor ao caso. Tal situação ainda agrava quando o objeto da discussão é um crime de competência do tribunal do júri, onde cada jurado que compõe o conselho de sentença é parte direta da sociedade e, em regra, sem qualificação jurídica que lhe propicie um mínimo de isenção, a qual já está eivada pelo sensacionalismo midiático e o juízo de valor atribuído ao caso, acontecendo de antecipar até mesmo o próprio veredicto no íntimo dos jurados, situação confortável para a promotoria que tem ao seu lado a mídia, auxiliando na sua tese de acusação. 
Válido ainda ressaltar a ingerência da mídia no devido processo legal. O princípio do devido processo legal apresenta-se como se fosse gênero dos quais os demais princípios que regem a relação processual são espécies. Servindo como base para os demais princípios, o devido processo legal assegura inúmeros outros postulados como os princípios do contraditório e da ampla defesa. Sendo assim, quando se mitiga ou se afronta os princípios que estão intrinsecamente vinculados ao princípio do devido processo legal, consequentemente, estará maculando também este princípio - mor.

O princípio do devido processo legal está disposto no art. $5^{\circ}$, inciso LIV da nossa Carta Magna:

Art. $5^{\circ}$ Todos são iguais perante a lei, sem distinção de qualquer natureza, garantindo-se aos brasileiros e aos estrangeiros residentes no país a inviolabilidade do direito à vida, à liberdade, à igualdade, à segurança e à propriedade, nos termos seguintes:

LIV _ ninguém será privado da liberdade ou de seus bens sem o devido processo legal (BRASIL, 2014, p. 23).

Moraes (1999, p.112) apresenta o seguinte conceito sobre o tema:

O devido processo legal configura dupla proteção ao indivíduo, atuando tanto no âmbito material de proteção ao direito de liberdade quanto no âmbito formal, ao assegurar-lhe paridade total de condições com o Estado-persecutor e plenitude de defesa (direito à defesa técnica, á publicidade do processo, á citação, de produção ampla de provas, de ser processado e julgado pelo juiz competente, aos recursos, à decisão imutável, à revisão criminal).

Como já tecido os comentários a respeito dos princípios da ampla defesa e do contraditório e, partindo do ponto que o devido processo legal é um princípio que engloba de certa forma os demais, a mídia também consegue com seu poder persuasivo macular essa garantia, podendo-se citar como exemplo a prisão preventiva decretada com base no clamor público ou comoção social; o que é inconstitucional, pois configura uma antecipação da pena, ferindo assim o referido postulado.

2.2 O princípio da presunção de inocência e sua violação pela mídia

O princípio da presunção de inocência, também chamado de princípio da nãoculpabilidade, está previsto no artigo 5º inciso LVII da Constituição Federal de 1988. Tal princípio é uma garantia processual conferida ao acusado pela prática de uma infração penal, concedendo-lhe a prerrogativa de não ser considerado culpado até o trânsito da sentença penal condenatória. 
Moraes afirma que, em regra, direitos constitucionais definidos como direitos fundamentais democráticos e individuais são de eficácia e aplicabilidade imediata. E a própria Constituição Federal, em uma norma síntese, determina esse fato, expressando que as normas definidoras dos direitos e garantias fundamentais têm aplicação imediata (MORAES, 1999).

O referido autor acrescenta ainda que o princípio da presunção de inocência é um dos princípios basilares do Estado de Direito. E como garantia processual penal, visa à tutela da liberdade pessoal, salientando a necessidade de o Estado comprovar a culpabilidade do indivíduo, que é de forma constitucional presumido inocente, sob pena de retrocesso ao Estado de total arbítrio. (MORAES, 1999).

Pode-se inferir que o princípio da presunção da inocência mostra-se como um dos princípios mais importantes do ordenamento jurídico pátrio. Sob a égide de tal premissa, o agente delituoso estará protegido até a sentença penal acusatória transitada em julgado de uma sanção penal antecipada em que não foi garantido ao agente o contraditório e a ampla defesa.

Além da Constituição Federal, o princípio da presunção da inocência também está previsto na Declaração Universal dos Direitos do Homem de 1948, que prevê em seu artigo XI:

Todo homem acusado de um ato delituoso tem o direito de ser presumido inocente até que a sua culpabilidade tenha sido provada de acordo com a lei, em julgamento público no qual lhe tenham sido assegurada todas as garantias necessárias à sua defesa (DUDH, 2014, p. 1888).

Além dos diplomas legais e morais acima mencionados, a de se ressaltar ainda o Pacto de San Jose, assinado em 1969, que também faz menção ao referido postulado em seu artigo $8^{\circ}$, inciso II, o qual aduz que "toda pessoa acusada de um delito tem direito a que se presuma sua inocência, enquanto não for legalmente comprovada sua culpa" (CADH, 2014, p. 1929).

Pode-se aduzir a partir da presença do princípio em análise em pactos internacionais, que a garantia da presunção da inocência transcende as fronteiras e limites nacionais, sendo também assegurada a nível constitucional em outros países.

Tal princípio coloca em choque o jus puniendi do Estado em face do jus libertatis do cidadão, cabendo ao julgador, diante do caso concreto, estabelecer qual deles deve prevalecer.

É oportuno destacar algumas passagens doutrinárias a respeito da conceituação da garantia da presunção da inocência. Távora (2011, p. 55) afirma que:

O reconhecimento da autoria de uma infração criminal pressupõe sentença condenatória transitada em julgado (art. 5 , inc. LVII da CF). Antes deste marco, somos presumivelmente inocentes, cabendo à acusação o ônus probatório desta demonstração, além do que o cerceamento cautelar da liberdade só pode ocorrer em 
situações excepcionais e de estrita necessidade. Neste contexto, a regra é a liberdade e o encarceramento, antes de transitar em julgado a sentença condenatória, deve figurar como medida de estrita exceção.

Lima (2011, p. 11) acrescenta que:

\begin{abstract}
Com a Constituição Federal de 1988, o princípio da presunção de não culpabilidade passou a constar expressamente no inc. LVII do art. $5^{\circ}$ : "Ninguém será considerado culpado até o trânsito em julgado de sentença penal condenatória".

Consiste no direito de não ser declarado culpado senão mediante sentença transitada em julgado, ao término do devido processo legal, em que o acusado tenha se utilizado de todos os meios de prova pertinentes para a sua defesa (ampla defesa) e para a destruição da credibilidade das provas apresentadas pela acusação (contraditório).
\end{abstract}

Também é válido ressaltar o reconhecimento deste princípio basilar por parte da jurisprudência pátria em aplicabilidade concreta. Veja-se:

HABEAS CORPUS. ROUBO SIMPLES. FIXAÇÃO DE REGIME PRISIONAL MAISGRAVOSO. AÇÃO PENAL EM ANDAMENTO. PRESUNÇÃO DE INOCÊNCIA. SÚMULA444/STJ. 1. De acordo com o princípio da não culpabilidade, ações penais em andamento, do mesmo modo que não podem agravar a pena-base, não constituem fundamento para a fixação de regime prisional mais gravoso. 2. Ordem concedida. (STJ - HC: 199814 SP 2011/0051416-2, Relator: Ministro SEBASTIÃO REIS JÚNIOR, Data de Julgamento: 03/11/2011, T6 SEXTA TURMA. Data de Publicação: DJe 28/11/2011)

HABEAS CORPUS. ROUBO SIMPLES. FIXAÇÃO DE REGIME PRISIONAL MAISGRAVOSO. AÇÃO PENAL EM ANDAMENTO. PRESUNÇÃO DE INOCÊNCIA. SÚMULA444/STJ. 1. De acordo com o princípio da não culpabilidade, ações penais em andamento, do mesmo modo que não podem agravar a pena-base, não constituem fundamento para a fixação de regime prisional mais gravoso. 2. Ordem concedida. (STJ - HC: 199814 SP 2011/0051416-2, Relator: Ministro SEBASTIÃO REIS JÚNIOR, Data de Julgamento: 03/11/2011, T6 SEXTA TURMA. Data de Publicação: DJe 28/11/2011)

Uma questão bem instigante sobre o princípio da presunção da inocência, que tem fomentado debates no mundo jurídico, é a possiblidade de execução provisória do acórdão penal condenatório prolatado em grau recursal, mesmo que estejam pendentes recursos aos tribunais superiores.

O STF, no julgamento do Recurso Extraordinário com Agravo (ARE) 964246, que teve repercussão geral reconhecida, entendeu pela possiblidade de execução provisória de acórdão penal condenatório proferido em grau de recurso, ainda que sujeito a recurso especial ou extraordinário, não compromete o princípio constitucional da presunção de inocência afirmado pelo artigo $5^{\circ}$, inciso LVII, da Constituição Federal.

No seu voto, o Ministro Teori Zavascki afirmou que toda pessoa acusada tem o direito de presunção da inocência garantido enquanto não se comprova sua culpabilidade. A própria sentença condenatória está sujeita à revisão pelo tribunal superior, caso haja manejo de 
recurso. É nesse grau de jurisdição (grau de recurso) que se exaure o exame sobre a matéria fática e provas carreadas ao processo. Com exceção da revisão criminal, é nas instâncias ordinárias que se esgota a possibilidade de exame de fatos e provas, uma vez que os recursos de natureza extraordinária não configuram desdobramento do duplo grau de jurisdição, por não se prestarem ao reexame da matéria fático-probatória. O Ministro alude que a execução da pena na pendência de recursos de natureza extraordinária não compromete o núcleo essencial do pressuposto da não culpabilidade, na medida em que o acusado foi tratado como inocente no curso de todo o processo ordinário criminal, observados os direitos e as garantias a ele inerentes, bem como respeitadas as regras probatórias e o modelo acusatório atual.

Sob essa argumentação, em outubro de 2016, o STF reafirmou a possibilidade de execução de pena após condenação em segunda instância, o que, no posicionamento da maioria dos Ministros, não compromete o princípio constitucional da presunção de inocência. Tal posição é a que tem vigorado até então.

Por conseguinte, acresça-se que desse princípio-alicerce emergem outros de mesma valia, como, o direito à ampla defesa, o contraditório, o direito de recorrer em liberdade, o duplo grau de jurisdição, os quais guardam íntima relação com o princípio em estudo, garantindo a concretização do devido processo legal, e evitando os riscos de uma decisão precipitada por parte do magistrado.

Feitas as devidas considerações a respeito do princípio do estado de inocência, é oportuno agora avaliar e demonstrar como a mídia, representada pela imprensa e materializada pelas notícias e informações apresentadas pelos meios de comunicação, fere e se insurge contra essa premissa constitucional.

Como já afirmado neste trabalho, a mídia exerce função essencial à sociedade através do fornecimento de informações emergentes. As informações que mais chamam atenção são notoriamente as que envolvem casos policias, incluídos dentro da seara penal, que dividem posicionamentos, que incutem um juízo de valor ao consciente das pessoas, causando uma comoção social e firmando a opinião pública.

É indiscutível que a liberdade de imprensa deve prevalecer em detrimento da censura, porém o que não pode, é desvirtuar a função dessa imprensa, que geralmente condena de forma imediata aquele indivíduo que esteja relacionado como suspeito da prática de uma conduta delituosa, suprimindo as garantias individuais.

O poder da mídia é tão forte que chega a direcionar os atos da vida cotidiana dos cidadãos, assim como ela consegue enaltecer determinado fato, consegue também impregnálo de impressão pejorativa. Barbosa (2003, p. 113) leciona: 
Quanto ao poder, à relação entre a chamada grande imprensa, as elites e os detentores do poder aparecem na forma daquilo que Mattiussi (1997) chama de "denuncismo": o uso da imprensa para legitimar as atitudes de uma autoridade política ou conferir tratamento pejorativo aos fatos a ela relacionados. A mídia cria, portanto, mocinhos e bandidos, heróis e derrotados.

Ao atribuir uma autoria delitiva a alguém, a mídia não faz nenhuma análise acerca da culpa do agente, consequentemente, ela faz um pré-julgamento, passando o sujeito a ser considerado culpado por todos, não sendo respeitada a garantia constitucional do estado de inocência.

O dilema, porém, não se concentra apenas nisso. Caso a mídia confirme sua imputação noticiada nos meios de comunicação, sua aposta resulta fundada e confirmada. Contudo, caso aponte erroneamente um delito a um sujeito, e posteriormente, caia por terra essa afirmação, seja por qualquer circunstância atinente ao caso, a exposição da moral da pessoa já foi totalmente maculada e denegrida, prejudicando muitas vezes até uma possível retratação.

Depreende-se do disposto acima que a liberdade de imprensa deve cessar no momento em que começa a violar os direitos de qualquer cidadão. Não resta dúvida que a livre propagação e divulgação de notícias e informações foram um avanço democrático conquistado pela sociedade, entretanto, tal divulgação deve ser pautada na proteção da imagem do sujeito, o qual é detentor de garantias constitucionalmente asseguradas.

2.3 Institutos jurídicos de reparação à ofensa promovida pela violação midiática aos direitos e garantias individuais

Após ter o direito violado, surge para o cidadão a prerrogativa de acionar a máquina judiciária a fim de solucionar, ou ao menos, recompensar de alguma forma o prejuízo que sofreu.

Vale destacar primeiro a figura da retratação, prevista no art. 26 da lei 5.250/67 (Lei de Imprensa). Retratar nada mais é do que posicionar-se contrário a uma declaração anteriormente feita, ou seja, é desdizer, desculpar, desmentir.

A mídia ao emitir notícia ou informação falsa sobre algo ou sobre alguém pode usar dos próprios meios de comunicação para desculpar-se publicamente pelo erro cometido. Há de se convir que, a retratação não é uma forma eficaz de sanar todos os prejuízos causados por uma declaração inverídica, porém, amenizaria os efeitos causados pela publicidade de determinado fato. 
Um segundo meio de oportunizar a defesa do sujeito que foi alvo de especulação falsa por parte da imprensa, é o direito de resposta, com previsão legal no capítulo IV da Lei de Imprensa e no art. $5^{\circ}$, inciso V, da Constituição Federal. O direito de resposta é o direito que uma pessoa tem de se defender de críticas públicas no mesmo meio em que foram publicadas.

Refere-se, portanto, ao direito de oferecer uma resposta ou retificação relativa a informações inexatas ou ofensivas emitidas em prejuízo de determinada pessoa ou pessoas, por meios de difusão legalmente regulamentados (televisão, rádio, etc.) e que se dirijam ao público em geral (SANKIEVICZ, 2010, p. 31). Assim como a retratação, o direito de resposta mostra-se apenas como um paliativo, quando se fala em violação de direitos e garantias fundamentais.

Ressalte-se que, não obstante o Pleno do STF tenha declarado que a Lei de Imprensa não tenha sido recepcionada pela Constituição Federal de 1988, o instituto do direito de resposta ou retratação ainda encontra previsão no ordenamento pátrio, no próprio texto constitucional, bem como no Pacto de São José da Costa Rica:

Embora o Pleno do STF tenha declarado não recepcionado pela Constituição de 1988 a Lei Federal n 5.250/67, no julgamento da ADPF no 130, a impetração não perdeu seu objeto porque o direito de resposta ainda encontra previsão legal no art. $5^{\circ}$, inc. V, da CF e no art. 14 do pacto de São José da Costa Rica. (...) (STJ. 6 ${ }^{\text {a }}$ Turma. RMS 14.577/DF, Rel. Min. Nefi Cordeiro, julgado em 11/11/2014).

Outra forma ressarcir os prejuízos causados pela divulgação de uma notícia falsa pela mídia, é a ação por danos morais e a imagem, prevista no art. $5^{\circ}$, inciso $\mathrm{V}$, da Constituição Federal. Dano moral é aquele que traz como consequência ofensa à honra, à liberdade, ao respeito, à psique, à saúde, ao nome, ao crédito; sem necessariamente ocorrer prejuízo econômico.

É comum ouvir falar de indenizações pagas pelas redes televisivas de repercussão de imagens quando estas violam direitos da personalidade das pessoas, como a honra, o nome. Pode-se citar a título de exemplo o famoso caso da "Escola Base", em que os donos e funcionários da escola localizada no bairro da Aclimação, na capital São Paulo, foram acusados de suposta prática de abuso sexual de crianças que ali estudavam.

Sem verificar a veracidade dos fatos, a mídia rapidamente difundiu a notícia no país inteiro, todavia, posteriormente, foi constatada a inocência dos acusados, caindo por terra todas às informações alavancadas pelos meios de comunicação, mostrando-se como exemplo cabal da violação ao princípio de presunção da inocência, gerando dever de indenização a sete veículos de informação que divulgaram a reportagem, uma vez que, tais fatos levaram a depredação e falência da escola. Neste sentido, leia-se: 
Indenizações determinadas pela Justiça no caso Escola Base passam de R 8 milhões. Os réus são sete veículos de comunicação que divulgaram reportagens sobre o caso e o governo do Estado de São Paulo. Ainda tramitam recursos no STJ (Superior Tribunal de Justiça) $^{36}$.

Mais adiante os autores da ação são identificados e o fato narrado em franca exemplificação do tema ora debatido:

O casal Icushiro Shimada e Maria Aparecida Shimada, dono da escola, e Maurício Monteiro de Alvarenga, motorista que servia ao colégio, foram acusados, em 1994, pela polícia de São Paulo de abuso sexual de crianças que estudavam na escola. Os três foram ameaçados de morte e a escola foi depredada e faliu. Inocentados, entraram com ações por danos morais pedindo indenização ${ }^{37}$.

Na passagem que segue o Superior Tribunal de Justiça, em sede recursal, acolheu as indenizações contra o governo do estado de São Paulo e os veículos de comunicação que difundiram a notícia:

Contra o governo paulista, ganharam em todas as instâncias. Em novembro de 2002, o STJ condenou o governo do Estado de São Paulo a pagar R $\$ 250$ mil a cada um dos autores da ação. No total, com juros e correções, a indenização passa de R $\$ 1$ milhão - que ainda não foi pago. A Folha e o „O Estado de S.Paulo“e também foram condenados a pagar indenizações de $\mathrm{R} \$ 250$ mil para cada um dos três autores da ação. Os dois jornais perderam em segunda instância e a condenação alcança, em valores corrigidos, cerca de R\$ 1,3 milhão. Embora haja recurso no STJ, a Folha fechou acordo com os autores da ação no valor de $\mathrm{R} \$ 880$ mil. Foi o primeiro acordo do $\operatorname{caso}^{38}$.

Ainda sobre as indenizações pagas pelos meios de comunicação:

A rádio e a TV Bandeirantes ganharam em primeira instância, mas as sentenças foram anuladas pelo Tribunal de Justiça. Há uma nova sentença julgando improcedente a demanda -já com recurso de apelação. O SBT foi condenado a pagar R\$ 300 mil, mais juros e correção, para cada um dos três autores da ação. A Editora Abril também já teve sentença confirmada pelo TJ. No caso da revista "Isto É", a condenação foi de R 120 mil (mais juros e correção) para cada um dos autores da ação ${ }^{39}$.

$[\ldots]$

Ainda na mesma notícia, O STF também foi favorável e manteve as indenizações fixadas:

No último dia 7 de agosto, o ministro Celso de Mello, do STF, não acolheu um recurso da TV Globo de São Paulo que tentava livrar a emissora da indenização aos

\footnotetext{
36 Folha de São Paulo. Indenizações do caso Escola Base já superam os $\mathrm{R} \$ 8$ mi. Disponível em: <https://www1.folha.uol.com.br/fsp/cotidian/ff2610200609.htm>. Acesso em: 01 jun. 2018.

37 idem.

38 idem.

${ }^{39}$ idem.
} 
proprietários da Escola Base por danos morais. A decisão mantém a condenação fixada pela Justiça de São Paulo, de R \$ 1,35 milhão.

$[\ldots]$

A Justiça entendeu que "o direito de informação e a liberdade de imprensa se sustentam no cuidado com a honra e dignidade das pessoas" 40 .

$[\ldots]$

Deve-se antes de qualquer coisa, buscar a efetivação do princípio da presunção da inocência diante a difusão de notícias por parte dos meios de comunicação, fazendo com que ele seja efetivado e respeitado, de modo a frear, impor limites, aos abusos provocados pela imprensa.

Repercussão não é sinônimo de ridicularizarão, nem de especulação. Muitas vezes a mídia sensacionalista acaba desvirtuando seu foco ao noticiar determinado fato sem nenhuma fundamentação palpável.

\section{CONSIDERAÇÕES FINAIS}

Ao final deste trabalho científico, constata-se que os meios de comunicação brasileiros, hodiernamente, não ponderam, nem atentam às garantias individuais de um cidadão, ao difundir uma notícia sem prévia verificação jurídica referente à veracidade probatória quanto ao que se está divulgando.

Por outro lado, é evidente que a mídia exerce um papel de utilidade pública ao decodificar a linguagem jurídica, e facilitar aos cidadãos o entendimento do desenrolar processual. Contudo, na maior parte das vezes, é sabido que a imprensa acrescenta um juízo de valor naquilo que noticia, distorcendo fatos, muitas vezes gerando danos irreparáveis à figura do acusado e aos seus direitos e garantias assegurados constitucionalmente.

Observou-se que em um sentido não meramente formal e político, mas substancial e social de democracia, o Estado de Direito equivale à democracia, no sentido que esta reflete, além da vontade da maioria, os interesses e necessidades vitais de todos. Neste sentido, o garantismo instrumentaliza-se como marco teórico que preconiza a limitação e a disciplina dos poderes públicos, voltado a determinar o que estes devem ou não deve proceder.

Concebeu-se, então, que em uma perspectiva substancial da democracia, as garantias, sejam liberais ou sociais, exprimem de fato os direitos fundamentais dos cidadãos em contraponto aos poderes do Estado, os interesses dos fracos respectivamente aos dos fortes, a

\footnotetext{
${ }^{40}$ idem.
} 
tutela das minorias marginalizadas ou dissociadas em relação às maiorias integradas, as razões de baixo relativamente às razões do alto.

Quanto ao respeito às garantias individuais do cidadão, ou seja, principalmente no tocante ao princípio da presunção da inocência, tal premissa deve ser respeitada pelos veículos de difusão informativa. Se no bojo dos processos judiciais, é assegurada constitucionalmente ao indivíduo esta garantia até que se tenha uma sentença condenatória, por que tem que ser diferente quando se fala de mídia? Especialmente quando esta propaga em massa verdadeiros decretos condenatórios prévios, que podem interferir no resultado dos julgamentos não somente sociais dos casos concretos, mas, lamentavelmente, também no resultado dos julgamentos judiciais destes mesmos casos?

Constatou-se que quando isso ocorre, mesmo que o indivíduo prejudicado tenha em seu favor institutos jurídicos, cujo objetivo seja mitigar a dor e o sofrimento experimentado com a inadequada publicação, longe estão de neutralizar o sentimento de injustiça amargado e propagada a perder da vista nesta sociedade da informação, onde tudo que se publica ganha proporções alarmantes em curto espaço de tempo.

Observou-se que da forma como os fatos são propagados, é frontal a ofensa ao princípio da presunção do estado de inocência. E que tal princípio deve ser observado em todos os âmbitos, jurídicos e sociais, como forma de preservar não só a figura do acusado, mas também da própria justiça, garantindo a dignidade da pessoa humana, princípio-mor e regente de todos os demais.

Por fim, é necessário destacar que o trabalho buscou esclarecer que o papel informativo da mídia deve sim ser contemplado no Estado Democrático de Direito; o que não se pode é descurar de direitos e garantias individuais consagrados constitucionalmente, para agir de forma inconsequente ao prestar esse serviço. Ainda são precárias as formas de controle da atividade midiática, sendo comuns apenas as indenizações pagas pelos veículos de comunicação que noticiaram erroneamente determinado fato. Quando se trata de um controle prévio, percebeu-se que inexiste, ou ainda, que não se demonstra suficientemente eficaz para inibir a atividade dos diversos profissionais da imprensa.

Há, pois, irremediável ofensa aos ideais garantistas e, por conseguinte, aos ideais de um Estado Democrático de Direito. Nessa tônica, se percebeu que a questão processual penal e, portanto, dos direitos e garantias individuais do acusado, em especial o princípio do estado de inocência, resta irremediavelmente malferida pela prática da imprensa temerária. Porém, para além desta constatação, em se tratando de casos criminais emblemáticos, concluiu-se que 
é a própria credibilidade da justiça que é atingida, gerando desestabilidade social e desprestígio ao Poder Judiciário brasileiro.

\section{REFERÊNCIAS}

BARBOSA. Pedro Luis Navarro, apud, GREGOLIN. Maria do Rosário. Discurso Mídia: a cultura do espetáculo. São Paulo: Claraluz, 2003.

BRASIL. Constituição (1988). Constituição da República Federativa do Brasil. Vade Mecum acadêmico de direito Rideel. 19. Ed. Editora Rideel, 2014.

Decreto-Lei $n^{\circ}$. 2.848, de 07 de dezembro de 1940. Código Penal. Vade Mecum acadêmico de direito Rideel. 19. Ed. Editora Rideel, 2014.

BRASIL. Superior Tribunal de Justiça. HC 151773 AL 2009/0210233-7. Relator: Min. Laurita Vaz. Julgamento em: 14 de junho de 2011. Disponível em: <http://stj.jusbrasil.com.br/jurisprudencia/21107279/habeas-corpus-hc-151773-al-20090210233-7-stj>. Acesso em: 01 jun. 2018.

BRASIL. Superior Tribunal de Justiça. Recurso em Mandado de Segurança 14.577/DF, Relator Ministro Nefi Cordeiro. Julgamento em 11 de novembro de 2017. Disponível em: <https://www.conjur.com.br/dl/correio-braziliense-dar-direito.pdf>. Acesso em: 01 jun. 2018.

BRASIL. Supremo Tribunal Federal. Habeas Corpus $\mathrm{n}^{\mathbf{0}} 100012$ - Pernambuco. Primeira Turma. Relator: Min. Ricardo Lewandowski. Julgamento em: 15 de dezembro de 2009. Disponível em <http://stf.jusbrasil.com.br/jurisprudencia/7406649/habeas-corpus-hc-100012pe>. Acesso em: 01 jun. 2018.

CHOUKR, Fauzi. A Teoria do Garantismo Penal no Direito e no Processo Penal. Boletim IBCCRIM, n. 77, abr.1999.

CONVENÇÃO AMERICANA DE DIREITOS HUMANOS (PACTO DE SAN JOSÉ DE COSTA RICA), 1969. Vade Mecum acadêmico de direito Rideel. 19. Ed. Editora Rideel, 2014.

DECLARAÇÃO UNIVERSAL DOS DIREITOS DO HOMEM, 1948. Vade Mecum acadêmico de direito Rideel. 19. Ed. Editora Rideel, 2014.

FERRAJOLI, Luigi. Direito e Razão: Teoria do Garantismo Penal. Prefácio da 1. ed. Italiana, Norberto Bobbio. 3. Ed. Ver. São Paulo: Editora Revista dos Tribunais, 2010. 
GRECO, Rogério. Curso de Direito Penal. Ed. 5. Rio de Janeiro: Impetus. 2005. p. 96.

LIMA, Renato Brasileiro de. Manual de processo penal, vol. 1. Niterói, RJ: Impetus, 2011.

MATOS, Margareth Carvalho de Andrade. O garantismo penal com base na dignidade da pessoa humana. Postado em 19 de setembro de 2012. Disponível em: <http://www.egov.ufsc.br/portal/conteudo/o-garantismo-penal-com-base-nadignidade-dapessoa-humana>. Acesso em: 01 jun. 2018.

MORAES, Alexandre de. Direito Constitucional. São Paulo: Atlas, 1999. penal. - Salvador: Editora Podivm, 2011.

NUCCI, Guilherme de Souza. Manual de processo penal e execução penal: 4 ed. rev., atual. e ampl. - São Paulo: Editora Revista dos Tribunais, 2008.

SANKIEVICZ, Alexandre. Quando é devido o Direito de Resposta? Revista de Direito Público (Porto Alegre), v. 8, p. 27-46, 2011. Disponível em: <http://www.trers.gov.br/arquivos/Quando_e_devido_o_direito_resposta.pdf>. Acesso em: 01 jun. 2018.

SANTOS, Moisés da Silva. A influência dos órgãos da mídia nos crimes de grande repercussão social em face da presunção de inocência do acusado. Jus Navigandi, Teresina, ano 18, n. 3548, 19 mar. 2013. Disponível em: <http://jus.com.br/artigos/23994>. Acesso em: 01 jun. 2018.

SCHÜTZ, Hebert Mendes de Araújo. Garantismo penal ameaçado - Uma abordagem sobre o clamor público gerado pelo sensacionalismo da mídia e sua influência na garantia dos direitos fundamentais. In: Âmbito Jurídico, Rio Grande, XIV, n. 89, jun 2011. Disponível em <http://www.ambitojuridico.com.br/site/index.php?n_link=revista_artigos_leitura\&artigo_id= 9583>. Acesso em: 01 jun. 2018.

TÁVORA, Nestor; ALENCAR, Rosmar Rodrigues. Curso de direito processual. Ed. 2011.

THE POWER OF PERSUASION OF THE MEDIA AGAINST THE PRINCIPLES 


\begin{abstract}
Criminal violence and lack of public safety are problems that have been very intense in the last decade. In this context, a great force of the media is observed in its most varied forms of propagation of the news. The research aims to analyze media interference in Brazilian criminal procedural dynamics, especially the principle of the state of innocence. The hypothetical-deductive method will be used and the bibliographical as well as the documentary will be used as research technique. A study committed to the current analysis of the interferences of the behavior of the national media in the light of the theoretical guarantor framework is taken care of.
\end{abstract}

Keywords: Media action. Presumption of the state of innocence. Criminal guilty. 